\title{
Structural Analysis of Offshore Cofferdam Subjected to Wave Load and Suction Pressure
}

\author{
Jeongsoo Kim*, Youn-Ju Jeong, Min-Su Park, Sunghoon Song \\ Department of Infrastructure Research, Korea Institute of Civil Engineering and Building Technology, Goyang, Korea \\ Email: jeongsookim@kict.re.kr
}

How to cite this paper: Kim, J., Jeong, Y.-J., Park, M.-S. and Song, S. (2018) Structural Analysis of Offshore Cofferdam Subjected to Wave Load and Suction Pressure. Open Journal of Civil Engineering, 8, 555-569.

https://doi.org/10.4236/ojce.2018.84040

Received: December 5, 2018

Accepted: December 25, 2018

Published: December 28, 2018

Copyright $\odot 2018$ by authors and Scientific Research Publishing Inc. This work is licensed under the Creative Commons Attribution International License (CC BY 4.0).

http://creativecommons.org/licenses/by/4.0/

\begin{abstract}
This study presented a novel circular cofferdam for offshore bridges consisting of ring segments and investigated its structural behaviors using ANSYS Mechanical. Because the bottom segment of the cofferdam which has a double sleeve cross-section was installed by suction, contact behaviors of the cofferdam wall and the lid plate during installation are important for design and the behaviors were also analyzed. Prior to numerical investigation of the bottom segment and complete cofferdam after dewatering, a suction modeling for structural analysis was proposed and evaluate by seepage analysis. Hydrodynamic loads applied to the cofferdam were also evaluated using panel method based on the potential flow theory. Through numerical analyses, structural behaviors of the cofferdam during installation were then investigated. First, contact behaviors between the lid plate and the wall were analyzed using different contact conditions imposed on the interface. Sharp stress increases were shown while the stress jumps were limited to contact area. Next, structural behaviors were investigated by considering seepage pressure. Using an axisymmetric seepage model, the total water pressure considering seepage was estimated and applied to structural analysis. The analysis results showed that strong effects of seepage on the stress change in cofferdam occurred and the seepage effects are necessary to be considered in design of the cofferdam induced by suction.
\end{abstract}

\section{Keywords}

Cofferdam, Suction Penetration, Hydrodynamic Analysis, Contact Analysis, Seepage Analysis, Double Hollow Cross-Section

\section{Introduction}

Although offshore construction involves big challenges including logistics and 
construction risks, many infrastructures such as renewable energy structures and fossil energy harvesting platforms are installed in the offshore site. Particularly for bridges, a coffer-dam is preferred to construct pier and foundation due to the following reasons. First, for nearshore and river, heavy logistics equipment and high capacity offshore cranes would be not available due to shallow water depth. Second, placing a footing of bridge pier under water pier improves structural performance, scour problem, and appearance; as the footing is placed lower, the pier stability increases, and the water flow cause less scour, as well as the footing covered with moss is hidden.

The cofferdam is a temporary structure to prevent from water and soil during excavation and the sheet-pile assembly type is conventional. The type is flexible to construction sites and cost-reduced. However, because most construction works are carried out by man-power, construction accidents and safety issues are strongly involved. Also, many struts and bracing members are required to ensure resistance and stiffness of cofferdams; this lowers constructability. On the other hand, a pre-fabricated cofferdam can minimize the problems of the sheet-pile type. This type of cofferdam is manufactured prior to offshore construction. The complete cofferdam is then towed to a construction site by barge and is installed by offshore cranes. Although the method significantly reduces offshore works, the application can be limited because large offshore cranes are required proportionally to cofferdam size; this causes construction costs.

Several studies were conducted to improve structural performance of the cofferdam with respect to design and construction. Rossow et al. (1987) [1] presented theoretical methods for design of cellular sheet pile cofferdam and established design procedure of the cofferdam. Bakir (1993) [2] conducted finite element analysis of cellular cofferdam to determine the interlocking tension in the sheet piles subjected to wave loads after construction and verified the results of the analysis by comparing with the recorded data. Wissmann et al. (2003) [3] investigated soil-structure interaction effects on sheet pile tensions using finite element analyses. Although theses research showed important considerations of cofferdam design, the cofferdam types were restricted to cellular types using sheet pile. On the other hand, prefabricated types of cofferdam are recently proposed and studied. Song et al. (2008) [4] introduced a huge double-wall steel boxed cofferdam applied to main bridge pier construction. Dhar et al. (2015) [5] presented a prefabricated cofferdam which consists of frames and side walls to construct deep water pile and pile-cap. Kim et al. (2017) [6] compared structural and hydrodynamic behaviors of large offshore segmented cofferdam with plane and corrugated cross section using numerical methods. These studies presented large prefabricated cofferdams and analyzed the behaviors. However, the previous research findings of papers are related to cofferdams which are installed using vibro-hammer and water jet.

As an alternative on the conventional cofferdams, a segmented circular cofferdam is presented in this paper. This cofferdam consists of several ring seg- 
ments. The proposed type needs less manual works to assembly than the sheet-pile cofferdam and offshore cranes with lower lift capacity than the completely prefabricated cofferdam. Furthermore, unlike the previous cofferdam, to fix the cofferdam to seabed, the bottom segment is installed by suction; this can lead to short construction period and minimum disturbance of seabed as well as marine environment. The installation procedure of the cofferdam is shown in Figure 1.

Because the cofferdam is subjected to suction and is exposed to seawater, reasonable load estimations on the loads are needed. Although there exist several studies related to suction penetration of anchor, most focused on soil behaviors during penetration [7] [8] [9], while few studies are interested in structural behaviors of suction caisson [10] [11]; suction pressure and its distribution on the plate and the wall are not clarified, and structural behaviors of the caisson are also not. For this reason, this study proposed an estimation of the suction pressure and its distribution on the cofferdam and conducted numerical analyses of the segmented cofferdam under installation. This paper assumed that the cofferdam has a double sleeve cross-section to resist offshore loading effectively and only dealt with the bottom segment. Also, structural behaviors of the segment were investigated considering suction and seepage pressures, as well as contact behaviors on the interface between the lid plate and the wall. The paper consists of six parts; 1) the segmented cofferdam is briefly introduced. Prior to structural analyses of the bottom segment of the cofferdam, 2) major external forces such as offshore loadings and suction-induced pressures are described. Also, 3) how to consider contact conditions between the segment and the lid were explained. In fourth part, 4) general descriptions of the numerical model for structural analysis to the bottom segment installed by suction are given. From numerical analyses, 5) effects of contact behaviors at the connection and seepage pressure are investigated and discussed. Finally, 6) the paper is wrapped up with several conclusions.
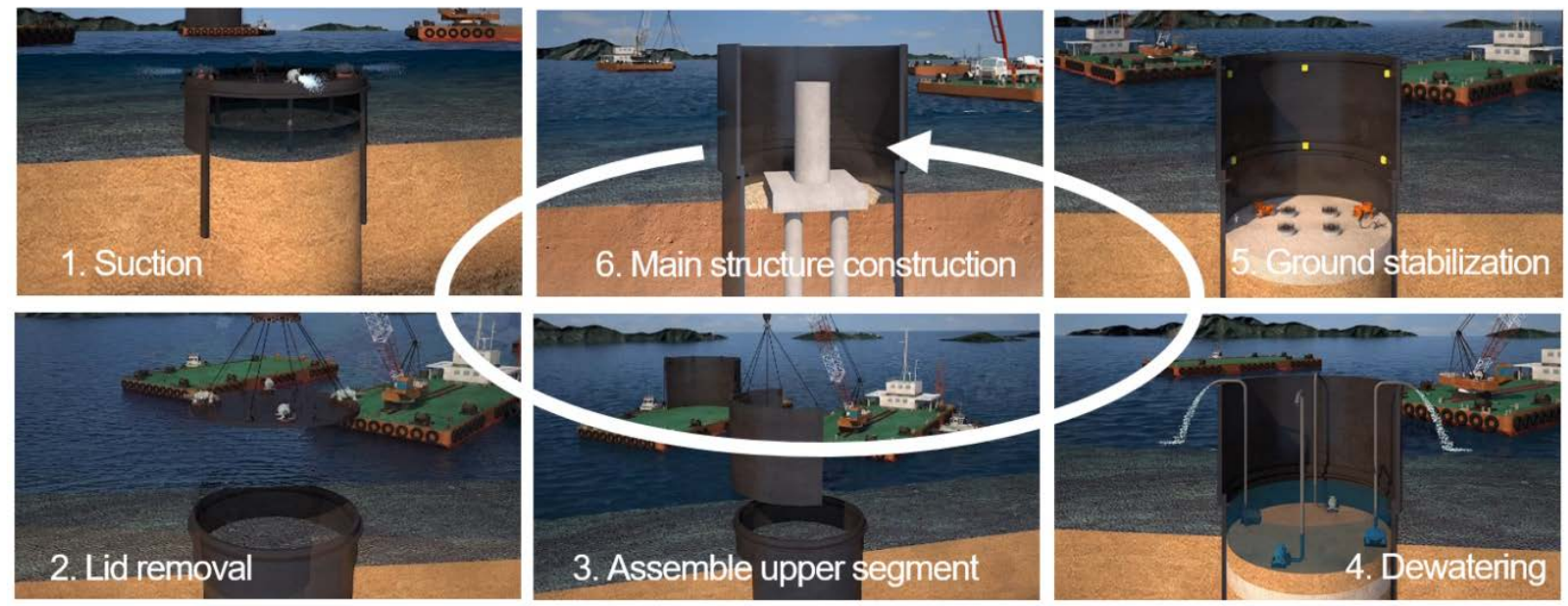

Figure 1. Segmented cofferdam installation procedure. 


\section{Estimation on External Force}

For penetration of the bottom segment of the proposed cofferdam, suction and water pressure are mainly important factor to examine the structural performances. In this section, how to estimate loads for suction and hydrodynamic pressure on the cofferdam is presented. Prior to the load estimation, the suction penetration mechanism of the bottom segment will be briefly described, and water pressure calculation of the segment considering seepage is then explained.

\subsection{Suction Penetration}

Suction penetration technology is widely used for offshore structure and the mechanism is well known; refer DNV-RP-E303 [12] which describes specific design and installation of suction anchor. A suction bucket is a pipe (skirt) enclosed at one-end with the lid plate (Figure 2) [13]. The bucket is penetrated into seabed with two stages: self-weight penetration and suction penetration. First, the bucket is being penetrated due to self-weight until the weight of the structure is in equilibrium with seabed resistance. Next, suction is applied by pumping out water from the inside of the bucket. This causes water pressure gradient between the inside and the outside of the bucket as well as seepage to weaken soil strength. As a result, the pressure difference forces the bucket to penetrate into soil more deeply.

The penetration technology was adopted to install the bottom segment of the proposed cofferdam. In the suction foundation design, limit equilibrium state of soil has been mainly focused while the bucket hasn't; vertical pressure on the lid

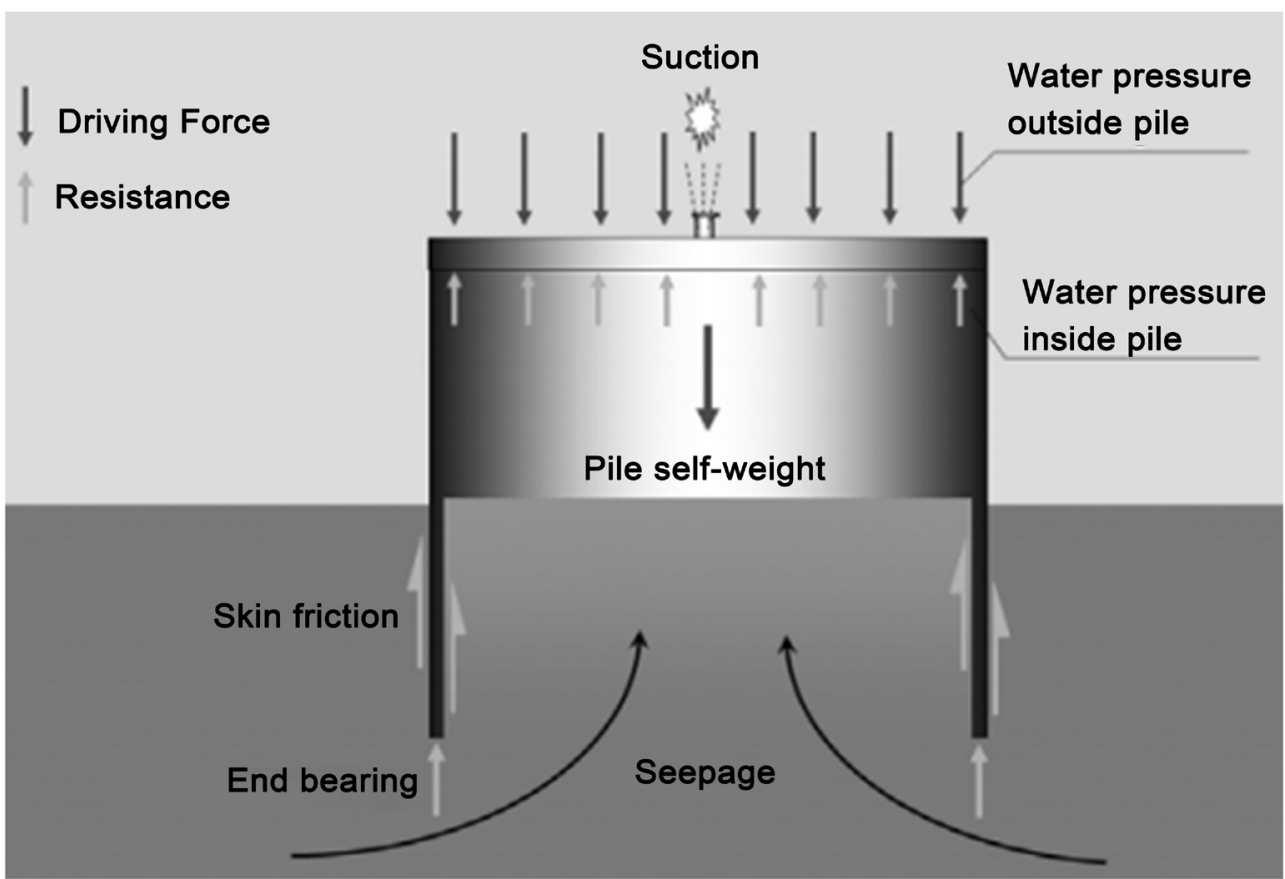

Figure 2. Mechanism of suction pile installation [13]

http://www.ssyenc.com/file/kor/tech/html/2012wi/2012_Winter_TechnicalInfo2.pdf. 
plate is mostly interested in to design water pumping and dimensions of skirt and diameter of the bucket. However, lateral forces are important for the proposed cofferdam because the diameter of the bottom segment is huge to create a dry work environment for construction of the foundation of offshore structures such as a bridge pier; the diameter is larger than $10 \mathrm{~m}$. Also, the wave diffraction effect is strong when the ratio of diameter to wavelength for cofferdam increases. Thus, reasonable estimations on water pressure including effects of suction and hydrodynamic behavior of wave are required to design the bottom segment.

\subsection{Suction Effect}

Suction effects were estimated using the one dimensional seepage theory. Seepage of the bottom segment in the one direction only was assumed as shown in Figure 3. Suction pressure was applied at A, consequently upward seepage occurred. Based on the energy conservation principle, total energy head at several points were then calculated as shown in Table 1; the datum was set at the points $\mathrm{A}$ and $\mathrm{D}$.

For given seepage problem, the hydraulic gradient $i$ is $p_{0} /\left(\gamma_{\mathrm{w}} \mathrm{h}_{2}\right)$. The pressure head means water pressure and can be described as follows:

$$
\begin{gathered}
u=-p_{0}+\gamma_{w} y \quad \text { (for water section) } \\
u=-p_{0}+\gamma_{w} h_{1}+\gamma_{w}(i+1) z \quad \text { (for soil section) }
\end{gathered}
$$

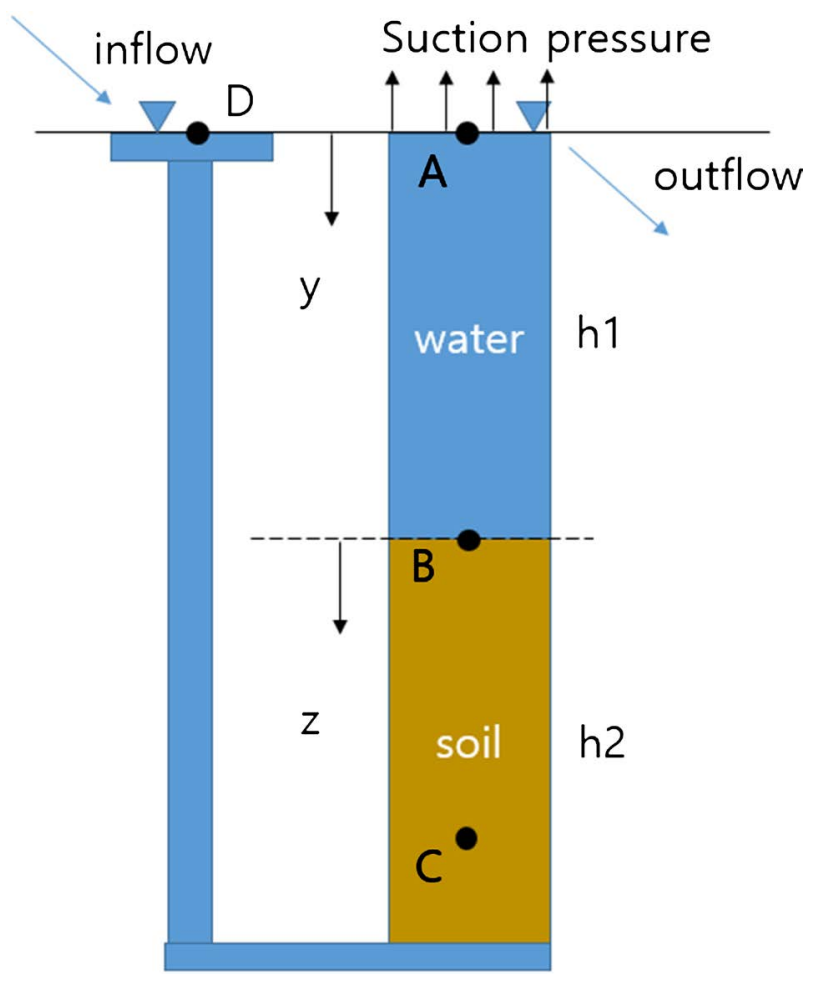

Figure 3. Idealization of suction penetration of the bottom segment. $h_{1}$ : water column height, $h_{2}$ : soil column height, $y$ : distance from the top end of water, and $z$. distance from the upper end of soil. 
Equations (1) and (2) show that the water pressure is consisted of pressure due to suction, water weight, and seepage. The suction term is constant while others change linearly according to positions. As a result, the bottom segment is subjected to bilinear distributed water pressure. In view of structural analysis, it is beneficial to apply each component of the water pressure in (1) and (2) instead of the total sum of the components; this approach enables effective analysis to identify main factor to increase stress and displacement of the structure. Thus, pressure loads are applied to the inside of the bottom segment as shown in Figure 4.

\subsection{Hydrodynamic Pressure}

Unlike the inside of the bottom segment, a wave load is considered for outside as well as hydrostatic pressure. Hydrodynamic analyses were conducted to estimate wave pressure and its distribution. Because the cofferdam has a large diameter to

Table 1. Water head calculation. $p_{0}$ : magnitude of suction pressure, $\gamma_{\mathrm{w}}$ : unit of water, and i: hydraulic gradient.

\begin{tabular}{cccc}
\hline \multirow{2}{*}{ Point } & \multicolumn{3}{c}{ Head $(\mathrm{m})$} \\
\cline { 2 - 4 } & Total head & Pressure head & Height head \\
\hline A & $-p_{0} / \gamma_{\mathrm{w}}$ & $-p_{0} / \gamma_{\mathrm{w}}$ & 0 \\
B & $-p_{0} / \gamma_{\mathrm{w}}$ & $-\mathrm{p}_{0} / \gamma_{\mathrm{w}}+h_{1}$ & $-h_{1}$ \\
C & $-p_{0} / \gamma_{\mathrm{w}}+\dot{z Z}$ & $-p_{0} / \gamma_{\mathrm{w}}+h_{1}+(i+1) Z$ & $-h_{1}-z$ \\
D & 0 & 0 & 0 \\
\hline
\end{tabular}

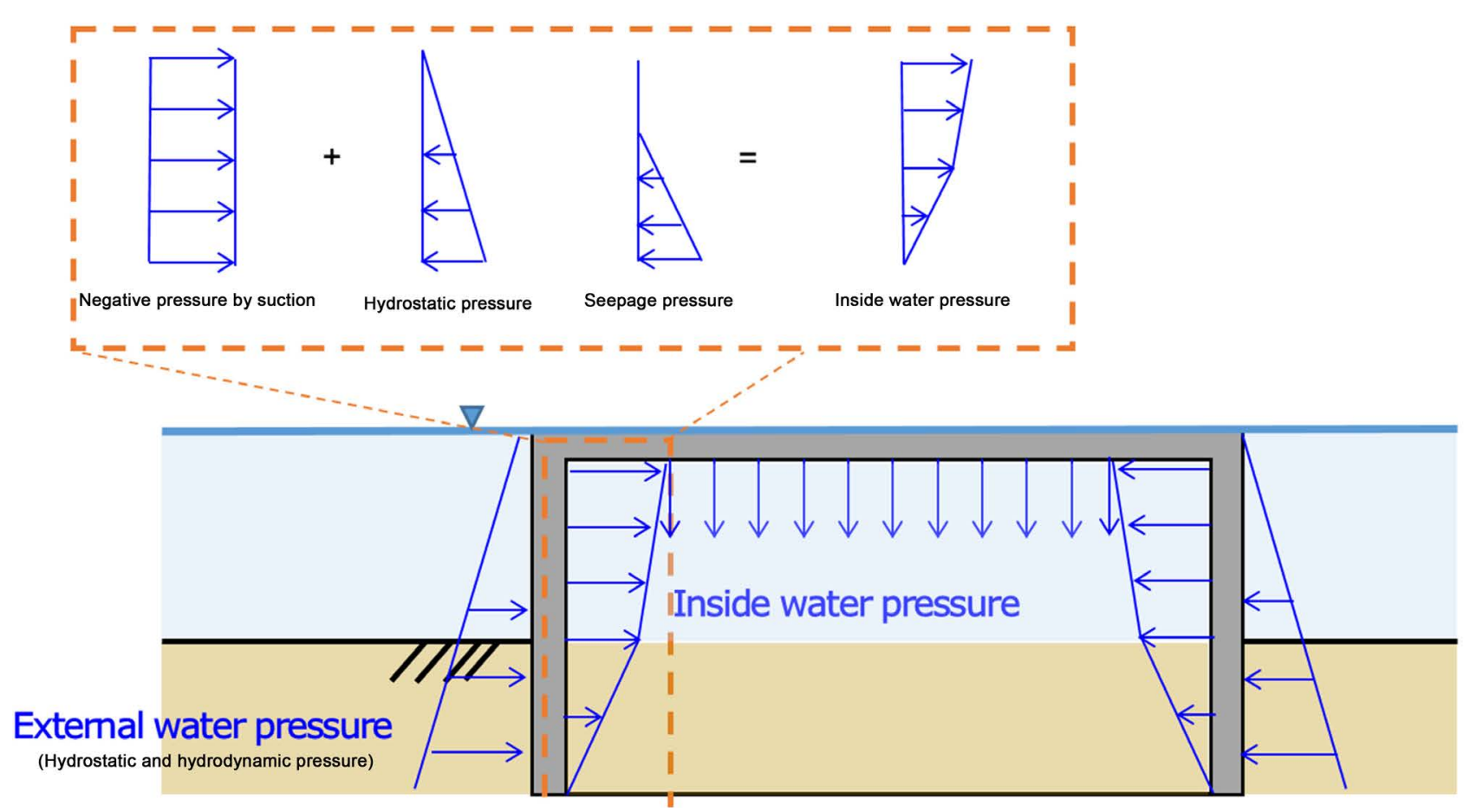

Figure 4. Water pressure components applied to inside of bottom segment. 
construct a main structure under dry conditions, wave diffraction effects cannot be ignored; it is known that the diffraction effect is large if the ratio of diameter to wavelength is greater than 0.2 , consequently calculating wave pressure using Morison equation is inadequate. For this reason, this study uses ANSYS AQWA ver. 15 to calculate hydrodynamic pressure. The numerical analysis program estimates wave pressure and distribution on structures, using the panel method based on potential flow theory for incompressible and inviscid water.

\subsection{Earth Pressure}

Displacements of the segment wall cause the lateral active and passive earth pressures. The conventional formulae for these earth pressures are based on the limit equilibrium state of soils. However, the methods overestimate the earth pressures when the soil is not in the limit equilibrium state. In this study, geostatic earth pressures were applied on the inside and the outside walls of the segment part which is embedded into soil with the lateral earth pressure coefficient of 1.0. To consider earth pressures due to lateral displacements of the wall, except the initial geostatic pressure, Winkler ground springs were imposed on the wall. The relation between the pressure and the displacement was assumed to be linear.

\section{Contact Effect on Bottom Segment}

After the bottom segment is embedded into soil, the lid plate is removed to install other segments and to consequently complete the cofferdam construction; thus, the lid plate, as a separate body from the bottom segment, must be able to take apart easily.

The plate which has a large diameter and is simply supported at the perimeter end is also subjected to suction pressure. This causes excessive deformation and stress and requires applying many stiffeners to the plate to prevent from them. For this reason, circumferential and radial stiffeners are placed on the plate as shown in Figure 5. Radial members act as a stiffener to decrease deflection of the lid, while the circumferential member is placed to release stress concentration; this high stress is caused by direct contact between the radial stiffeners of the lid and the segment wall.

Although the joint between the bottom segment and the lid effects on stress changes in the segment wall, the joint interface behaviors are not clearly known. The contact surfaces between the lid and the segment are as follows: 1) the bottom of the lid and the top end of the segment, and 2) the circumferential stiffener of the lid and the segment wall. Because of the ambiguity at the interfaces, the behaviors were idealized as shown in Figure 6. Three contact conditions were applied at the interfaces. First, assuming the lid and the segment are strongly connected by bolting, the rigid connection was applied. Another contact condition considered the translational forces to be transfer from the lid to the segment. Any effects due to bending of the lid were excluded. In the last condition, 


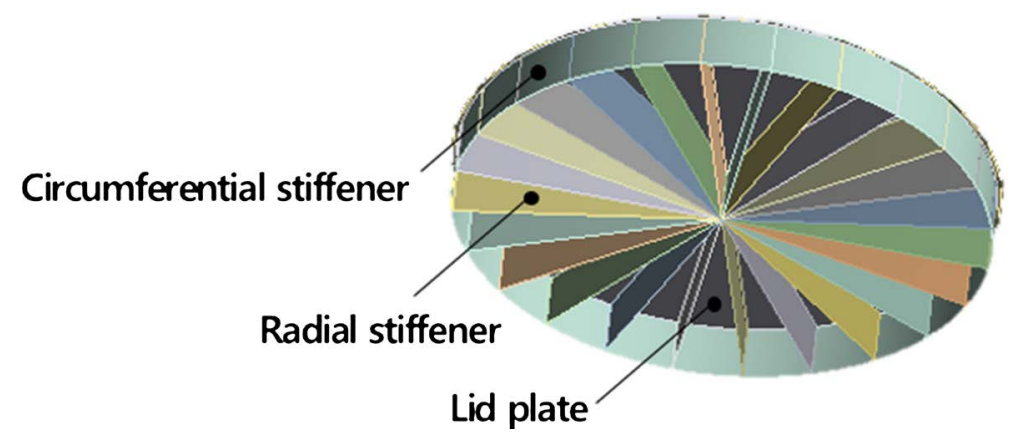

Figure 5. Lid plate and stiffeners.
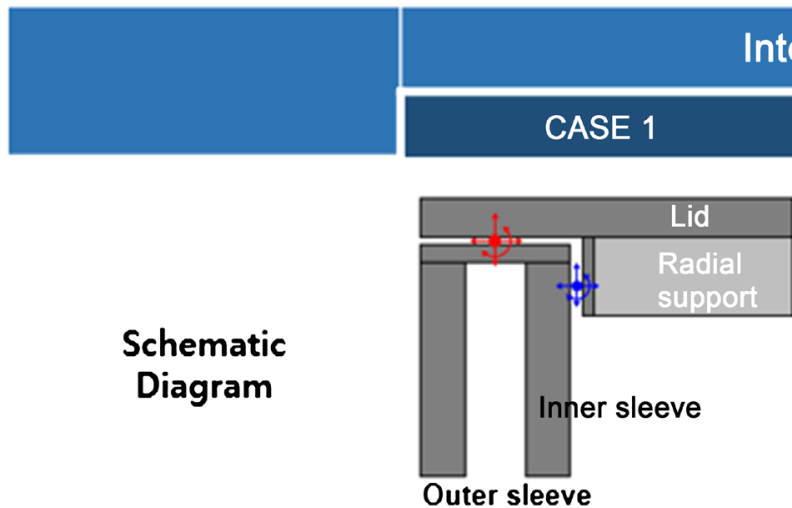

\section{Interface between lid and sleeves}

\section{Schematic Diagram}
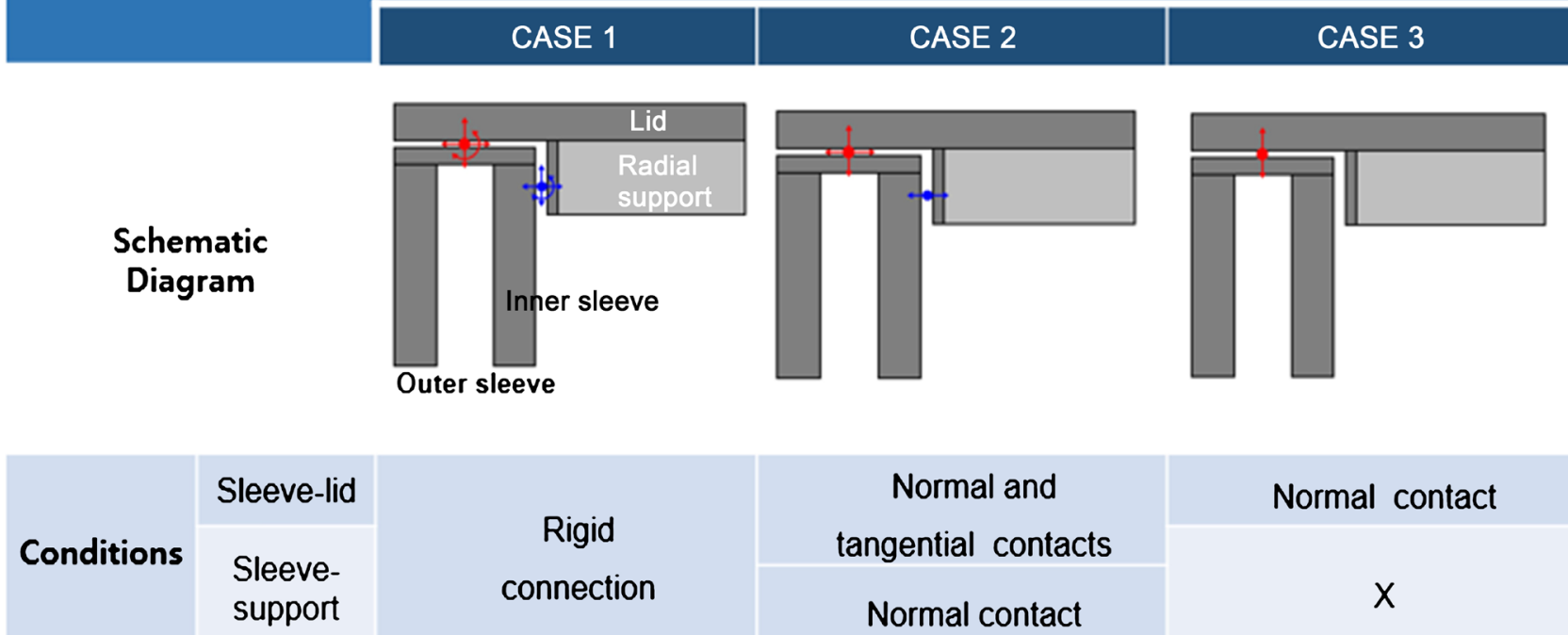

\section{Rigid \\ connection}

\section{Normal and}

tangential contacts

Normal contact
Normal contact

$x$

Figure 6. Contact conditions at the interface between the lid and the segment.

the normal contact force occurred only at the lid and the top end of the segment due to weak bolt connections.

\section{Model Description}

Structural analysis models were created to analyze contact effects and structural behaviors of the bottom segment subjected to suction, wave, and earth pressure loads. The cofferdam has a double sleeve cross section which has the outer diameter of $20 \mathrm{~m}$ and the inner diameter of $19.6 \mathrm{~m}$. The outer and inner sleeves are connected with vertical and horizontal stiffeners by welding; each sleeve and stiffeners have the thickness of $16 \mathrm{~mm}$. The bottom segment height is $15 \mathrm{~m}$.

Offshore and seabed conditions for Southern-west sea of Korea were determined, based on long-term measurement data of wind and wave as well as in-situ test data [14]. The target site has shallow sea with the average depth of $10 \mathrm{~m}$. The regular wave ( $H_{s}=1.0 \mathrm{~m}, T_{p}=6 \mathrm{~s} ; H_{s}:$ significant wave height, $T_{p}$ : wave period) with 1-year return period was applied to reproduce the cofferdam installation under waves with a mild fluctuation. The tidal current velocity is $0.176 \mathrm{~m} / \mathrm{s}$. 
From hydrodynamic diffraction analysis, the resultant wave force at the phase of $90^{\circ}$ is larger than other phases of the wave. So, the wave pressure data is then applied to structural model as an external force.

Although the seabed layers consist of multi-layers of loose sand $(0-4 \mathrm{~m})$, soft clay $(4-25 \mathrm{~m}$ ), and soft rock (more than $25 \mathrm{~m}$ ), the seabed was considered as a single soft clay layer. Several soil parameters were applied to the model as follows: saturated unit weigh of soil: $18 \mathrm{kN} / \mathrm{m}^{3}$, subgrade reaction modulus of soil: $5000 \mathrm{kN} / \mathrm{m}^{3}$.

The suction was assumed to cause uniform distributed pressure on the interior surface of the inner sleeve. Hydrostatic pressure and seepage were also applied to the interior surface for submerged and imbedded areas, respectively. Submerged unit weight of $67 \mathrm{kN} / \mathrm{m}^{3}$ for structural steel and unit weight of $10.06 \mathrm{kN} / \mathrm{m}^{3}$ for seawater were applied. The bottom of the segment was constrained to prevent from lateral displacements. The detailed external load distributions are shown in Figure 7, for suction initiation after self-weight penetration (model A) and during suction (model B). Note that water in the space between outer and inner sleeves partially offset hydrostatic pressure on the sleeves. Water pressures due to seepage exist only.

Model A was used to analyze the contact effect. Because the embedded length of the bottom segment is short, water pressures due to seepage were ignored. On the other hand, model B was used to compare seepage effects. To estimate the seepage pressure, a numerical analysis was conducted using an axisymmetric

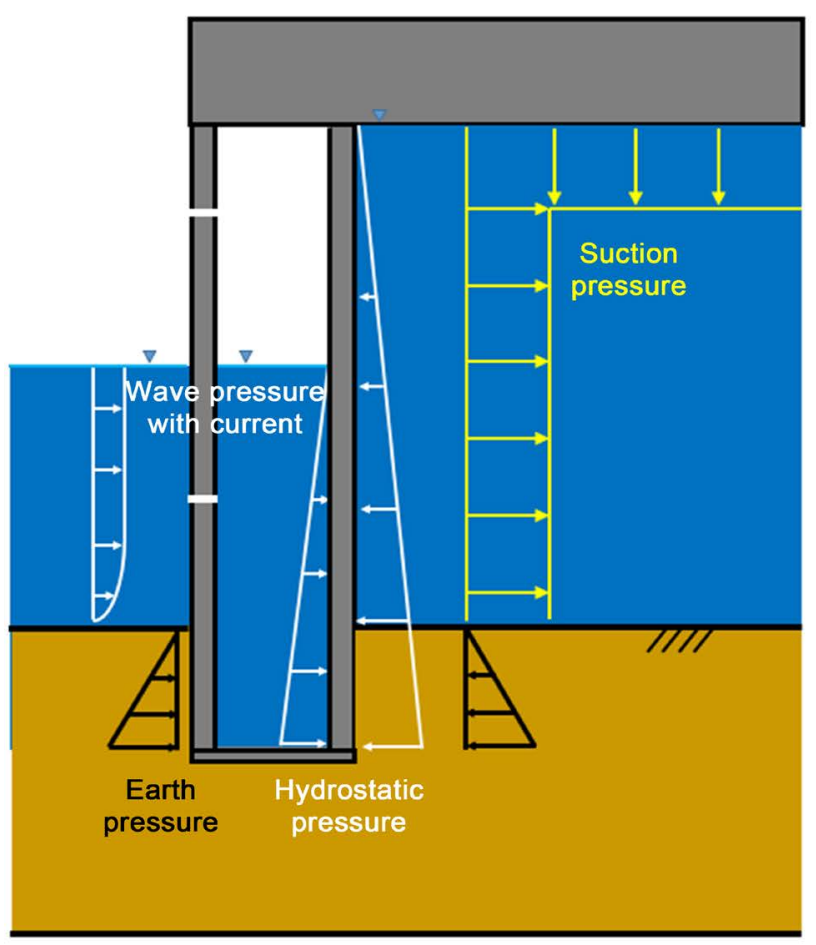

Model A: suction initiation

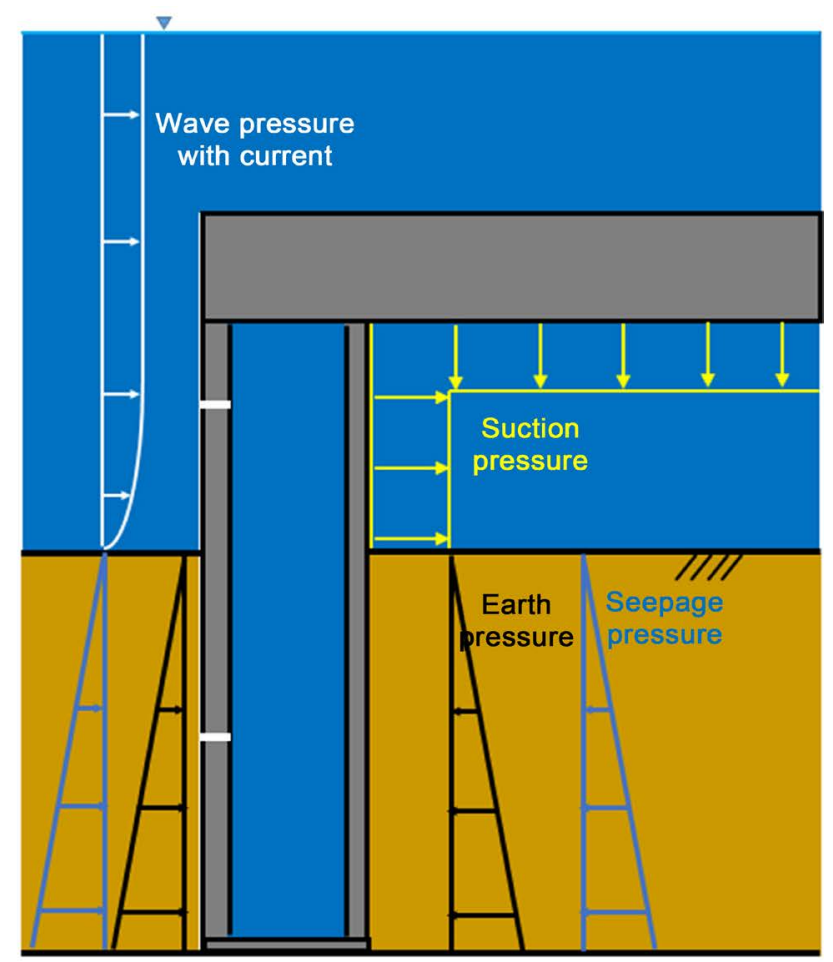

Model B: suction installation

Figure 7. Schematic diagram of load distribution during installation of the bottom segment. 
seepage model. Figure 8 shows total water pressure profile on the inner and outer surface when the bottom segment of the cofferdam is penetrated at the $10 \mathrm{~m}$ depth. The permeability coefficient of the seabed was assumed to be $0.005 \mathrm{~cm} / \mathrm{s}$. Note that the vertical axis in Figure 8 indicates vertical distance from the datum which is set at the top of the bottom segment. 5. Result Analysis and Discussion

\subsection{Contact Effect}

Stresses in the sleeves along the wall height were shown in Figure 9 and Figure 10. Particularly for Cases 1 and 2, stress changes were complex due to the contact between the segment walls and the stiffener of the lid; sharp stress jump indicated near the contact area and then disappeared. The stiff stress changes would be mostly caused by lateral contact forces from the radial stiffeners. However, contact effects were limited within the direct contact area. Thus, basic design of the cofferdam, such as a thickness, should be conducted for indirect contact area and detailed design of the stiffeners and reinforcements would be then conducted for the contact area.

In Figure 9, it is also shown that, by comparing with blue and red lines for the outer and inner sleeves near the vertical support, bending and lateral force of the lid causes sharp stress increases. Also, the inner sleeve seems to be governed by bending of the lid because smoother stress changes in the outer sleeve were overall observed. Inflection points of stress profile curves occurred due to the circumferential stiffeners between the walls.

Overall stress changes of the inner sleeve are relatively remarkable than the outer. This would be caused by water pressure due to suction; if water pressure due to self-weight is a major factor, stress profile along the height must be more proportional to vertical positions. Although suction pressure increased from $100 \mathrm{kPa}$ to $150 \mathrm{kPa}$, the pattern of stress profile was not changed; the stress magnitude
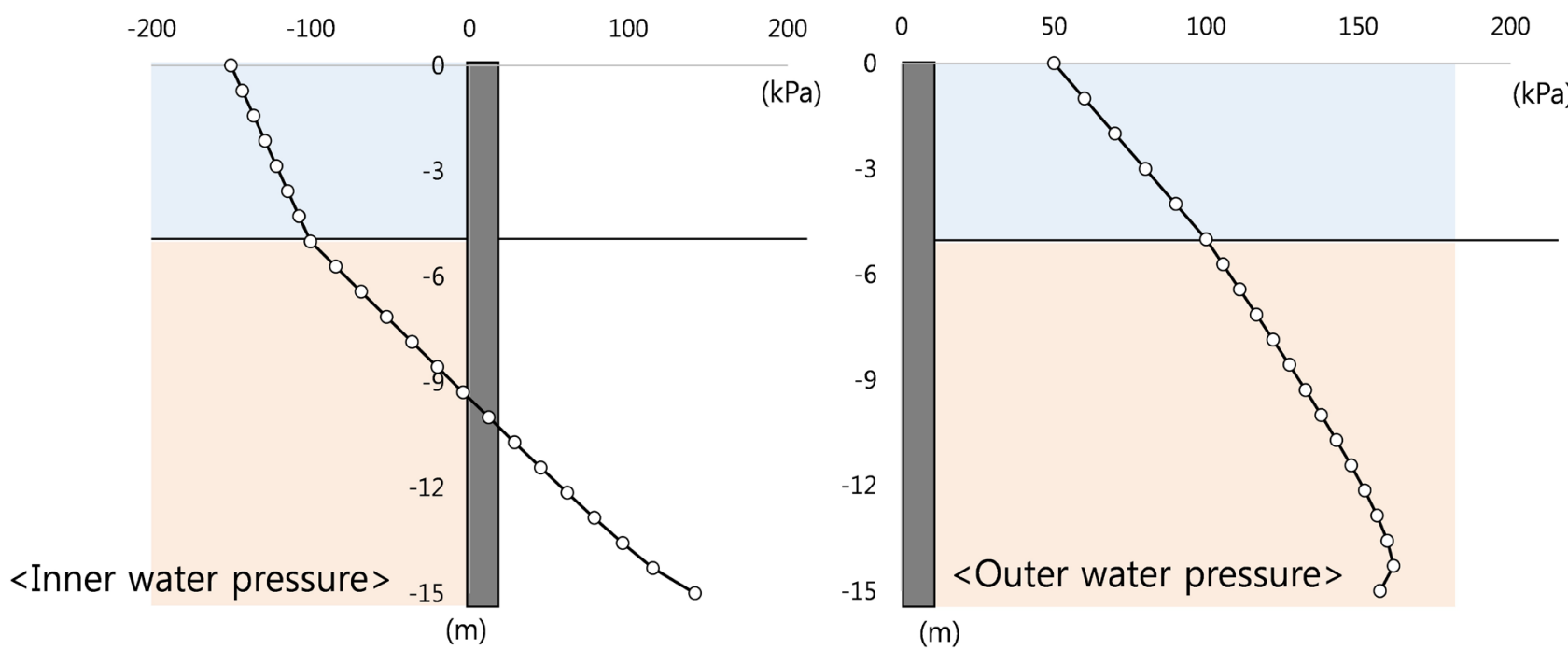

Figure 8. Total water pressure profiles. 
increased only. Thus, the magnitude of suction is the most important design factor of the bottom segment. Also, unexpectedly, the upper part of the outer sleeve has low stresses irrespective of contact condition. This means that effects of wave pressure with tidal current is small and could be ignored in the installation stage.

\subsection{Seepage Pressure Effect}

As shown in Figure 8, changes in water pressure due to seepage are smaller than hydrostatic pressure along the direction of height. However, near the skirt tip of the bottom segment, the seepage pressure for outer sleeve change not only made total water pressure to be nonlinear but also to be reduced as about $150 \mathrm{kPa}$; if there is no seepage and suction, the total water pressure is $200 \mathrm{kPa}$. For inner sleeve, total water pressure became from negative to positive along the height direction. If the seepage effects are ignored, total water pressure is zero at the
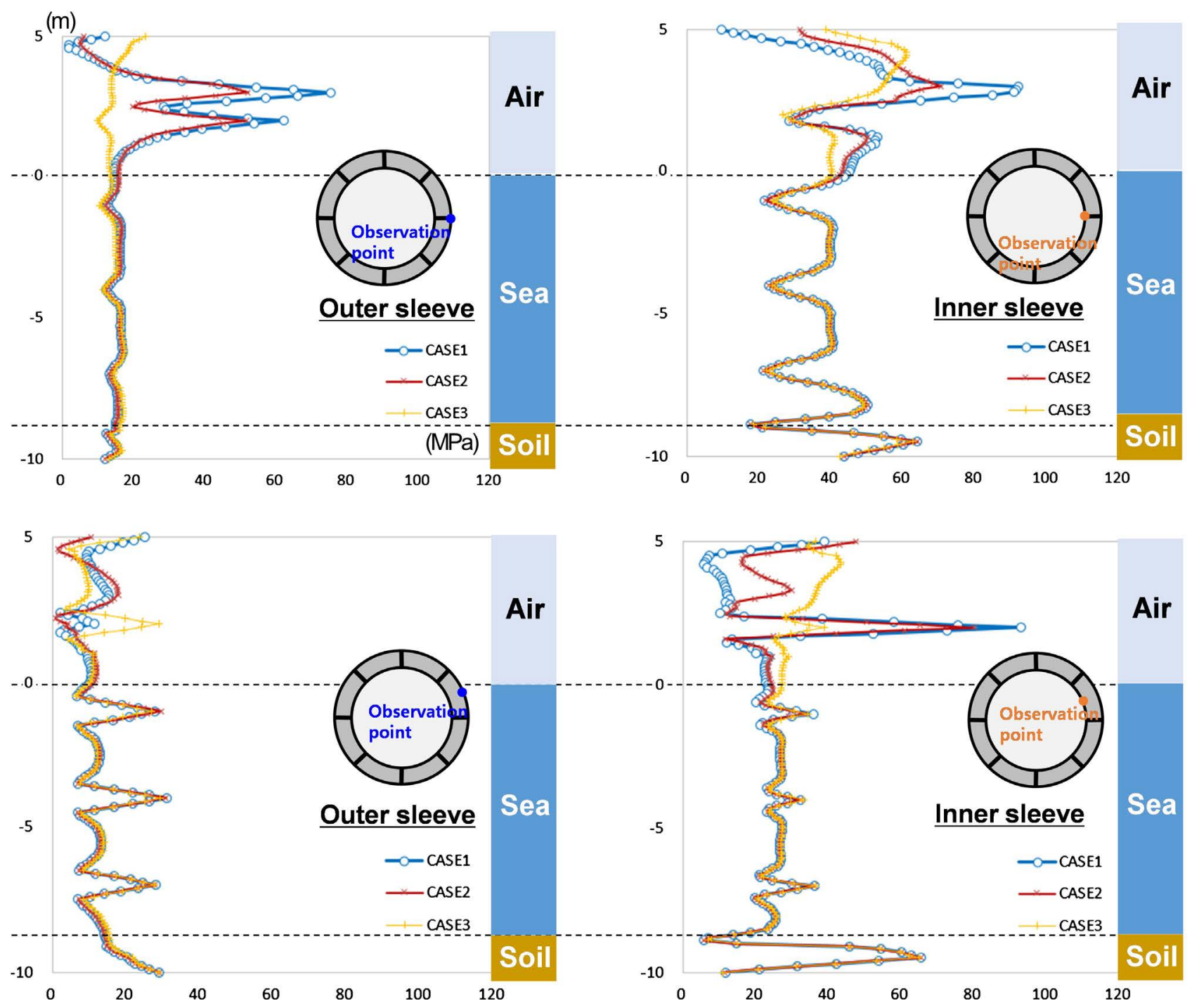

Figure 9. Stress profiles when suction initiation (suction pressure: $100 \mathrm{kPa}$ ). 


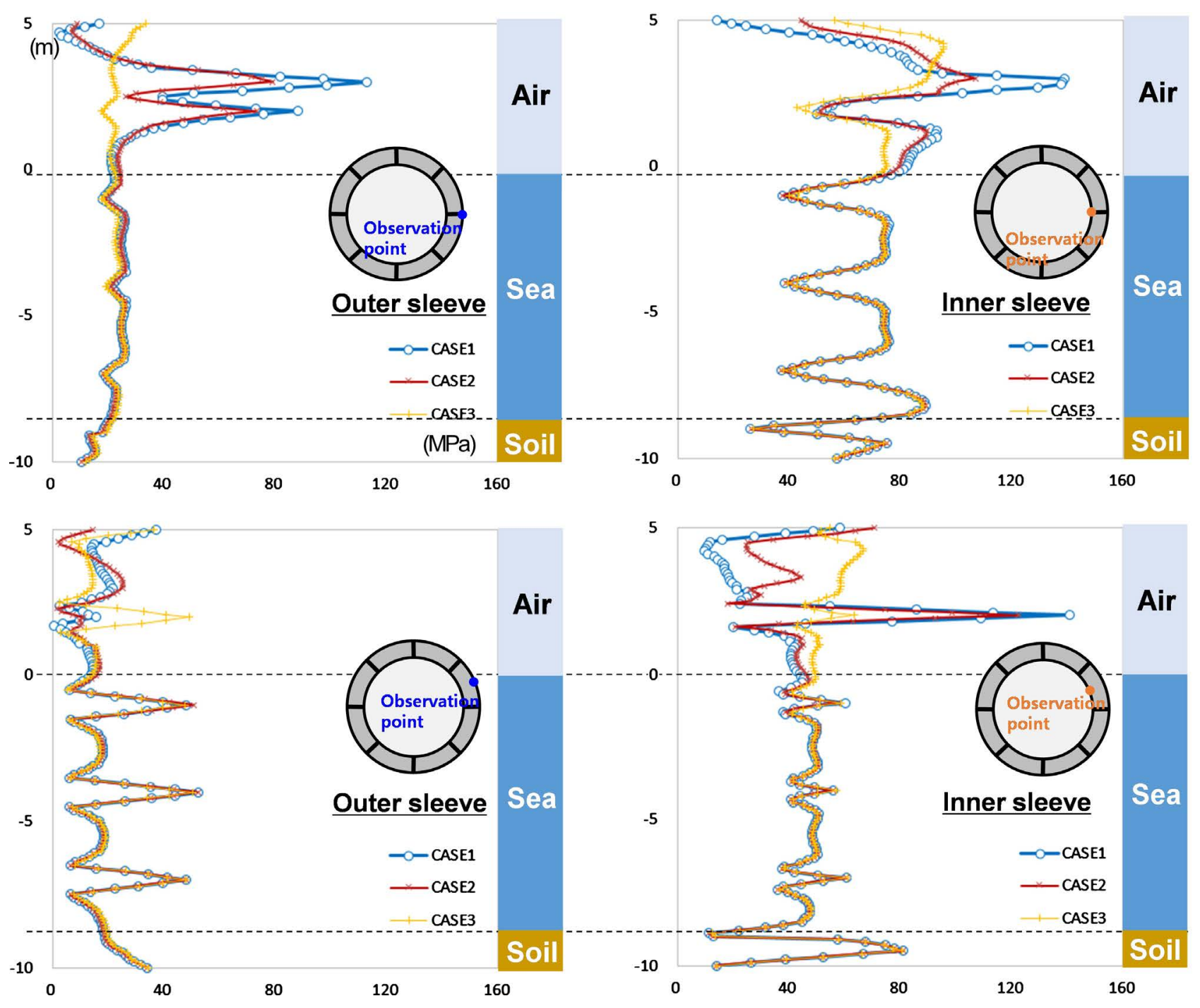

Figure 10. Stress profiles when suction initiation (suction pressure: $150 \mathrm{kPa}$ ).

$-15 \mathrm{~m}$; the maximum water pressure change due to seepage is about $130 \mathrm{kPa}$. Other numerical studies [15] [16] related to seepage analysis of suction caissons also reported significant changes in water pressures due to suction and emphasized on the consideration of the seepage effects in suction caisson design; however, because they were interested in reductions of the bearing capacities due to suction, the necessity of seepage pressure in structural design was not stated in these studies. From numerical seepage analysis in the present study, differences between static water pressure and water pressure with seepage are large with respect to magnitude and distribution. Therefore, seepage must be considered when structural behaviors of the bottom segment during installation are analyzed.

Stress profiles for model B with and without seepage pressure are shown in Figure 11 and Figure 12. Note that hydrostatic pressures on the sleeve walls disappear by offsetting as shown in Figure 7. The contact condition applied to 


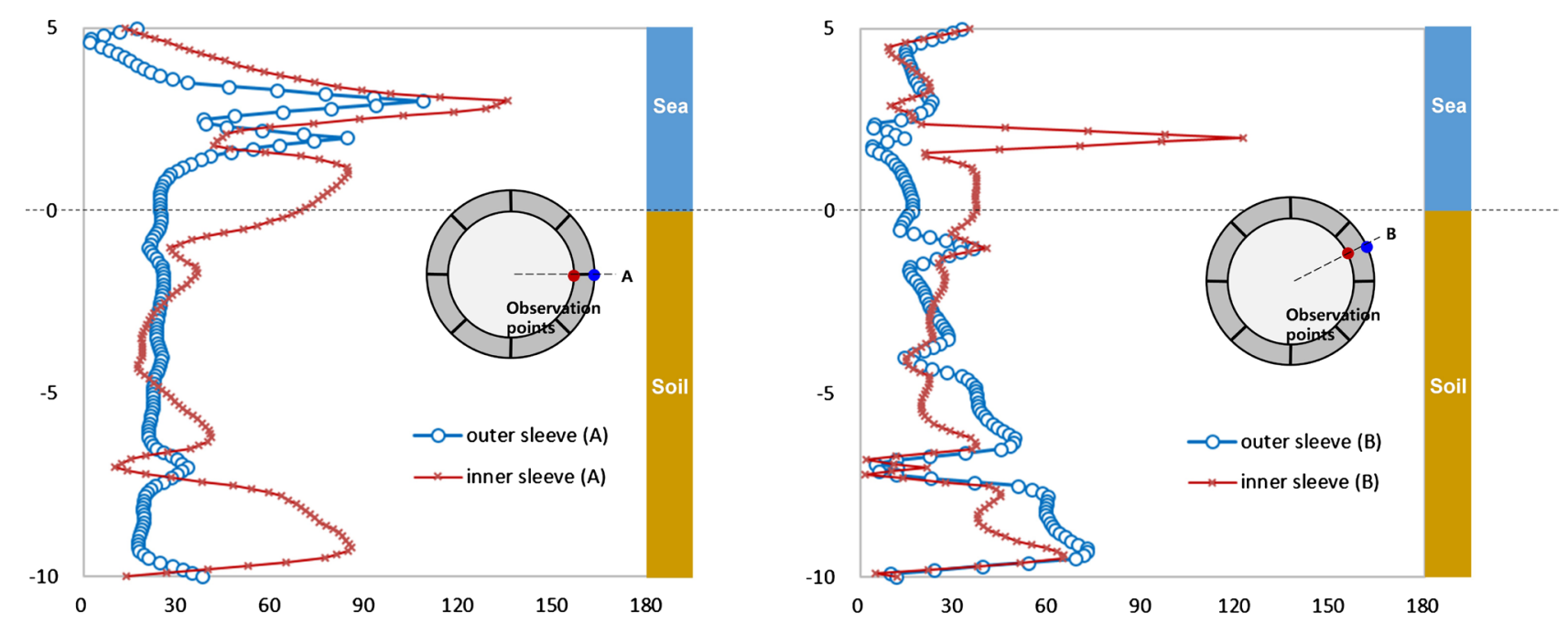

Figure 11. Stress profiles when suction installation without seepage pressure (suction pressure: $150 \mathrm{kPa}$, Contact condition: Case 1).
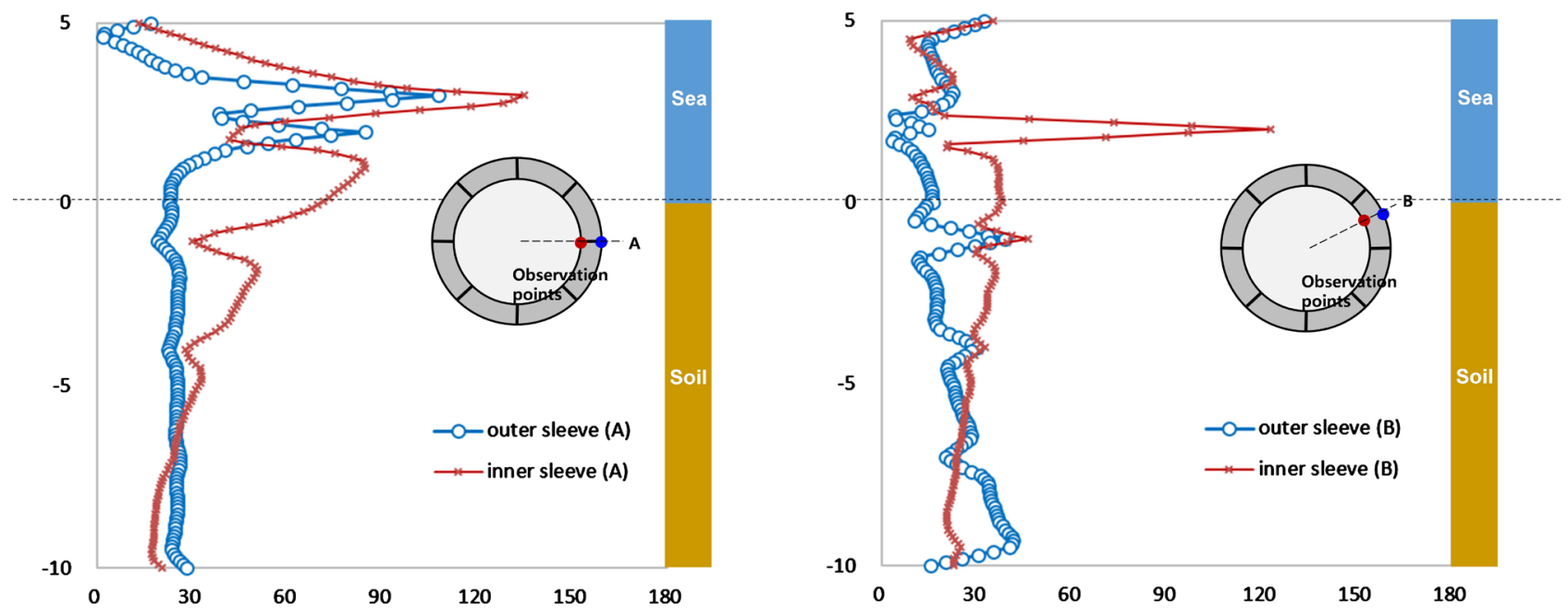

Figure 12. Stress profiles when suction installation with seepage pressure (suction pressure: $150 \mathrm{kPa}$, Contact condition: Case 1).

the interface was Case 1. It is shown that the seepage water pressure causes considerable difference between the stress profiles in Figure 11 and Figure 12. The maximum von Mises stresses of the models were closely same with each other because of contact effect between the lid and the segment wall. However, as penetrating the bottom segment and increasing water pressures due to seepage, stress profile patterns of the inner sleeve were significantly changed. The maximum stress increment of the inner sleeve is about $60 \mathrm{MPa}$ near the bottom. Stress increases also occurred in the outer sleeve; particularly for observation point $\mathrm{B}$, stresses became double near the bottom. The above results show that water pressure change due to seepage should be considered in the structural analysis of the type of cofferdams for design of stiffener arrangement and plate thickness.

\section{Conclusions}

This paper presented a large segmented cofferdam which is installed by suction 
and established a modeling of the cofferdam and external loads for structural analysis. Changes in water pressure due to suction, and consequently seepage were analyzed using a one dimensional seepage problem and the total pressure and distributions were evaluated using an axisymmetric finite element model. Also, contact effect was analyzed by comparing with results from structural models with different contact conditions. Through the above several analyses, the following conclusions were drawn.

1) Contact effects between the lid plate and the sleeve wall are limited to direct contact area. Although the sharp stress increase in the upper part of the sleeves is caused by bending and lateral forces transferred from the lid, the stresses rapidly disappear along the height.

2) Direct changes in water pressure due to suction are main design load factor of the cofferdam. Stress profile patterns are like the models with suction pressures of $100 \mathrm{kPa}$ and $150 \mathrm{kPa}$. If the bearing capacity of seabed is small, the cofferdam behaviors can be governed by other external loading factors.

3) Water pressure change due to seepage is overall linear. Although nonlinear seepage effects appear near the skirt tip, this area is small and can be ignored. However, it is required to reasonably estimate the boundary values at the tip. Two dimensional finite element analysis for seepage analysis can be a solution, but a simple formula would be proper in design.

4) Application of water pressure due to seepage causes significant changes in stress profile patterns of the inner sleeve. Except stress concentration area due to the contact effect, stresses of the inner sleeve increase along the height. On the other hand, stresses of the outer sleeve have the similar profile to that of the model without seepage pressure, while the stresses become larger.

5) Thus, seepage effects should be considered for basic design of the cofferdam and examination of contact effects is recommended to apply into the detailed design.

\section{Acknowledgements}

This study was supported by the Ministry of Land, Infrastructure and Transport, Project No: 16SCIP-B119960 (Development of Life-Cycle Engineering Technique and Construction Method for Global Competitiveness Upgrade of Cable Bridges).

\section{Conflicts of Interest}

The authors declare no conflicts of interest regarding the publication of this paper.

\section{References}

[1] Rossow, M., Demsky, E. and Mosher, R. (1987) Theoretical Manual for Design of Cellular Sheet Pile Structures (Cofferdams and Retaining Structures). No. WES/TR/ITL-87-5, Army Engineer Waterways Experiment Station, Information 
Technology Lab, Vicksburg.

[2] Bakir, B.S. (1993) Finite Element Analysis of Cellular Structures Subjected to Wave Loads. Ph.D. Dissertation, Iowa State University, Ames.

[3] Wissmann, K.J., Filz, G.M., Mosher, R.L. and Martin J.R. (2003) Sheet Pile Tensions in Cellular Structures. Journal of Geotechnical and Geoenvironmental Engineering, 129, 224-233. https://doi.org/10.1061/(ASCE)1090-0241(2003)129:3(224)

[4] Song, W.J., Wen, W.S., Lian Z.P. and Dong G.W. (2008) Construction Techniques for Deep Water Foundations of Main Piers of Dashengguan Changjiang River Bridge in Nanjing. Bridge Construction, 4, 3. (In Chinese)

[5] Dhar, B.C., Kafi, M.A. and Hoque, M. (2015) Construction of Deep Water Pile and Pile Cap by Using Prefabricated Steel Coffer Dam Technique. IABSE-JSCE Joint Conference on Advances in Bridge Engineering-III, Dhaka, 21-22 August 2015 325-330.

[6] Kim, J., Jeong, Y.J. and Park, M.S. (2017) Structural Behaviors of Cylindrical Cofferdam with Plane and Corrugated Cross Section under Offshore Conditions. International Journal of Emerging Technology and Advanced Engineering, 7, 334-340.

[7] Colliat, J.L., Boisard, P., Gramet, J.C. and Sparrevik, P. (1996) Design and Installation of Suction Anchor Piles at a Soft Clay Site in the Gulf of Guinea. Offshore Technology Conference, Houston, 6-9 May 1996, 13 p. https://doi.org/10.4043/8150-MS

[8] Andersen, K.H., Jostad, H.P. and Dyvik, R (2008) Penetration Resistance of Offshore Skirted Foundations and Anchors in Dense Sand. Journal of Geotechnical and Geoenvironmental Engineering, 134, 106-116. https://doi.org/10.1061/(ASCE)1090-0241(2008)134:1(106)

[9] Ko, J., Jeong, S. and Kim, J. (2017) Application of a Coupled Eulerian-Lagrangian Technique on Constructability Problems of Site on Very Soft Soil. Applied Sciences 7, Article ID: 1080. https://doi.org/10.3390/app7101080

[10] Madsen, S., Andersen, L.V. and Ibsen, L.B. (2013) Numerical Buckling Analysis of Large Suction Caissons for Wind Turbines on Deep Water. Engineering Structures, 57, 443-452.

[11] Kuo, Y.H., Wei, B.S. and Measamer, J. (2015) A Study on Suction Pile Shell Buckling and Soil Failure Utilizing Predicted and Real-Time Monitored Suction Pressures during Installation. The 25th International Ocean and Polar Engineering Conference, Kona, 21-26 June 2015, Article ID: ISOPE-I-15-493.

[12] DNV (2005) Geotechnical Design and Installation of Suction Anchors in Clay. DNV Recommended Practice RP-E303, Høvik.

[13] Kim, J. (2012) Review of Offshore Wind Turbine Foundation Focused on Suction Pile Penetration. Construction Technology Ssangyong, 1, 24-29. (In Korean)

[14] KEPRI (2013) Interim Design Basis Report: Test Bed for 2.5GW Offshore Wind Farm at Yellow Sea. (In Korean)

[15] Faramarzi, A., Faizi, K., Dirar, S., Mehravar, M. and Harireche, O. (2016) Modelling the Seepage Flow during Caisson Installation in a Natural Seabed. Proceeding of the 24th UK Conference of the Association for Computational Mechanics in Engineering, 31 March-1 April 2016, Cardiff, 150-153.

[16] Guo, Z., Jeng, D.S., Guo, W. and He, R. (2017) Simplified Approximation for Seepage Effect on Penetration Resistance of Suction Caisson in Sand. Ships and Offshore Structures, 12, 980-990. https://doi.org/10.1080/17445302.2016.1200450 